\title{
Urdimento
}

Revista de Estudos em Artes Cênicas E-ISSN: 2358.6958

\section{A cena política, a política da cena: Reflexões sobre modernidade na arquitetura teatral alemã}

Beatriz Magno Alves de Oliveira

\section{Para citar este artigo:}

OLIVEIRA, Beatriz Magno Alves de. A cena política, a política da cena: Reflexões sobre modernidade na arquitetura teatral alemã. Urdimento, Florianópolis, v. 1, n. 40, mar./abr. 2021.

do) DOI: http:/dx.doi.org/10.5965/1414573101402021e0207

Este artigo passou pelo Plagiarism Detection Software | iThenticate 
A cena política, a política da cena:

Reflexões sobre modernidade na arquitetura teatral alemã ${ }^{1}$

\title{
Resumo
}

Beatriz Magno Alves de Oliveira ${ }^{2}$

O presente trabalho teve como ponto de partida as proposições sobre espaço cênico trazidas pelo livro A revolução do teatro: conclusões sobre o Teatro dos Artistas de Munique do dramaturgo e encenador alemão Georg Fuchs. O artigo revisitou as arquiteturas teatrais desenvolvidas por artistas alemães do princípio do século XX e a partir delas, refletiu sobre as propostas políticas contidas nos trabalhos dos encenadores Max Reinhardt e Erwin Piscator. O objetivo aqui foi refletir sobre as relações entre espaço cênico e política, e como as mesmas foram determinantes na construção do teatro moderno.

Palavras-chave: Espaço cênico. Teatro político. Teatro alemão. Modernidade. Arquitetura teatral.

The political scene, the scene policy:

Reflections on modernity in German theatrical architecture

\begin{abstract}
The present work had as a starting point the propositions about scenic space brought by the book The revolution in the theater: conclusions concerning the Theater of the Artists of Munich of the German dramatist and director Georg Fuchs. The article revisited the theatrical architectures developed by German artists of the early 20th century and from them, reflected on the political proposals contained in the works of directors Max Reinhardt and Erwin Piscator. The objective here was to reflect on the relationships between scenic and political space, and how they were decisive in the construction of modern theater.
\end{abstract}

Keywords: Scenic space. Political theater. German theater. Modernity. Theatrical architecture.

\footnotetext{
${ }^{1}$ Este artigo foi elaborado a partir da dissertação de mestrado intitulada A cena como relevo, o teatro como festa: reflexões sobre a revolução do espaço teatral de Georg Fuchs realizada pela autora no Programa de Pós-Graduação em Artes Cênicas da Universidade Federal do Estado do Rio de Janeiro (PPGAC - UNIRIO) concluído no ano de 2020, sob orientação da Profa. Dra. Vanessa Teixeira de Oliveira e com apoio da Coordenação de Aperfeiçoamento de Pessoal de Nível Superior - Brasil (CAPES) - Bolsa Demanda Social de Mestrado.

${ }^{2}$ Bacharel em Cenografia e Indumentária. Mestre em Artes Cênicas e Doutoranda em Artes Cênicas pela Universidade Federal do Estado do Rio de Janeiro (UNIRIO). Professora no Curso Técnico em Teatro do programa Mediotec da Fundação das Artes de São Caetano do Sul (FASCS). beatriz.magno@gmail.com.

(9) http://lattes.cnpq.br/4509352138489191 (iD https://orcid.org/0000-0002-0685-3632
} 
La escena política, la política de la escena:

Reflexiones sobre la modernidad en la arquitectura teatral alemana

\section{Resumen}

El presente trabajo tuvo como punto de partida las propuestas sobre el espacio escénico que aporta el libro La revolución del teatro: conclusiones sobre el Teatro de los Artistas de Munich del dramaturgo y director alemán Georg Fuchs. El artículo revisó las arquitecturas teatrales desarrolladas por artistas alemanes de principios del siglo XX y, a partir de ellas, reflexionó sobre las propuestas políticas contenidas en las obras de los directores Max Reinhardt y Erwin Piscator. El objetivo aquí fue reflexionar sobre las relaciones entre espacio escénico y político, y cómo fueron determinantes en la construcción del teatro moderno.

Palabras clave: Espacio escénico. Teatro político. Teatro alemán. Modernidad. Arquitectura teatral. 
O presente trabalho pretende estudar o teatro proposto pelo teórico e dramaturgo alemão Georg Fuchs (1868-1949) em seu livro A Revolução do Teatro: conclusões sobre o Teatro dos Artistas de Munique ${ }^{3}$ de 1909. As reflexões teóricas desse autor serão analisadas em relação a outras experiências teatrais alemãs, buscando traçar relações entre espaço cênico e política. Vale a pena destacar que o livro de Fuchs, usado aqui como referência, foi abordado por encenadores importantes na reformulação da cena moderna como o russo Vsevolod Meyerhold (1874-1940) e o inglês Edward Gordon Craig (1872-1966). O Teatro dos Artistas de Munique foi projetado pelo arquiteto Max Littman (1862-1931) a partir das ideias de Georg Fuchs, sua construção integrou a Exposição de Munique (Ausstellung München) de 1908. Essa exposição ocorreu no local onde atualmente é o Bavarian Park, próximo a Theresienwiese no qual ocorre a tradicional Oktoberfest. Os prédios construídos para essa exposição, incluindo o Teatro dos Artistas, foram destruídos durante os conflitos da Segunda Guerra Mundial com exceção dos grandes pavilhões de exposições que hoje abrigam um museu sobre os meios de transporte. 
Figura 1 - Teatro dos Artistas de Munique (1908) - Fachada ${ }^{4}$

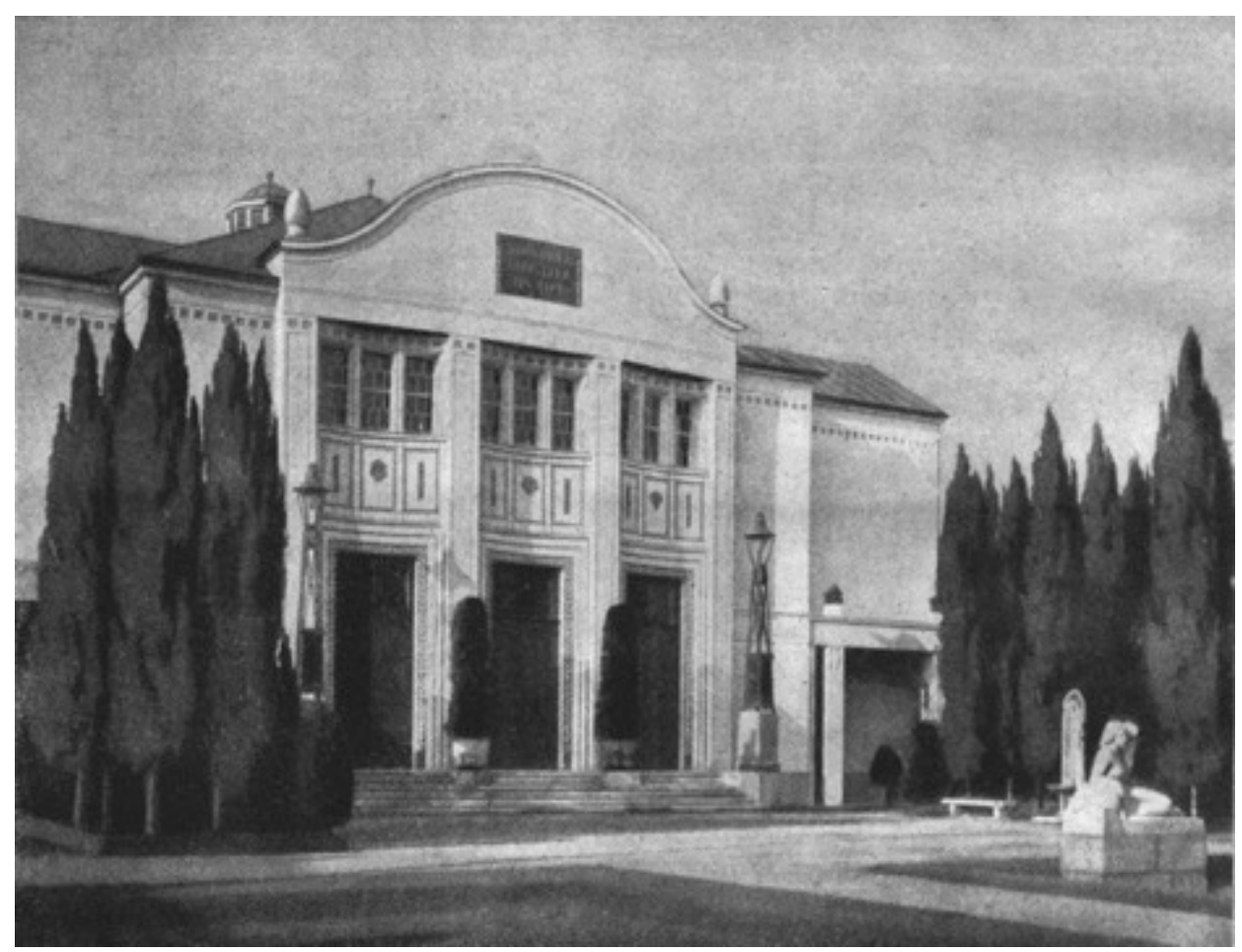

Durante as investigações a respeito do trabalho de Georg Fuchs, se fez necessário pensar as transformações do espaço cênico ocorridas nos anos iniciais do século XX especificamente no contexto alemão - principalmente, devido a questão central deste trabalho, de pensar arquitetura teatral e suas implicações político/sociais. Segundo Bernard Dort, no texto $A$ vocação política, é na relação palco e plateia que reside o caráter político do teatro. Ou seja, para o autor, o aspecto teatral que mais o aproxima de um evento político é a existência da dualidade palco-plateia. Não foi por acaso, portanto, que no momento histórico do início do século XX, em que existiram diferentes tentativas de transformações políticas e sociais, houve também inúmeras propostas de novos arranjos entre palco e plateia (Dort, 2010, p.367).

Semelhante ao que conceitua Dort, o autor Denis Guénoun, no livro A exibição das palavras, afirma que o teatro exige um público coletivo, reunido para a apresentação. Sendo assim, ele parte da tese de que "a convocação, de forma 
pública, e a realização de uma reunião, seja qual for seu objetivo, é um ato político" (Guénoun, 2003, p.14). Portanto, Guénoun entende que o teatro enquanto um evento público, de reunião coletiva, faz dele intrinsecamente político.

Em seu livro, Guénoun apresenta como ao longo da história do teatro, o sentido do termo grego théatron se deslocou da plateia (lugar de onde se vê) para o palco (lugar da representação). "O que é político, no princípio do teatro, não é o representado, mas a representação: sua existência, sua constituição, "física", por assim dizer, como assembleia, reunião pública, ajuntamento" (Guénoun, 2003, p.15). Contudo, houve uma tendência, no teatro ocidental, a um esquecimento da representação e a uma atenção maior ao representado, ou seja, ao objeto da representação: "[...] a plateia vai sendo mergulhada na penumbra, o palco vai sendo iluminado" (Guénoun, 2003, p.16). É a arquitetura, portanto, nas palavras de Guénoun, a instância política que ordena o teatro. Para ele, a forma circular é a maneira espontânea de organização de uma audiência, e por isso, está presente na maior parte das arquiteturas teatrais do Ocidente. Os teatros completamente retangulares e frontais, para Guénoun, apesar de alguns possuírem boa acústica e visibilidade, possuem uma "frieza - ausência desta misteriosa 'boa relação' entre o palco e a plateia [...] Mas o que importa não está aí. Nós o procuraremos [...] na origem política da representação teatral. E se fundamenta numa observação ingênua: o círculo é a disposição que permite que o público se veja" (Guénoun, 2003, p. 20).

No início do século XX aparecem diferentes propostas de modificação do espaço teatral. Tais transformações fazem sentido quando pensamos: no contexto artístico de renovação, de crise da representação e de surgimento dos movimentos de vanguarda; e no contexto histórico de tentativa de implementação de novas ordens políticas e econômicas. Essas propostas de transformação do espaço teatral variam de acordo com os objetivos de cada encenador. Por isso, torna-se evidente a relevância do estudo da espacialidade para a compreensão do contexto teatral alemão e do teatro proposto por Georg Fuchs. Em seus escritos, o autor propõe a ideia de cena relevo, na qual ele desloca sua preocupação do objeto da representação para o evento teatral como um todo. Ou seja, no teatro de Fuchs 
sua proposta cenográfica está completamente imbricada na sua proposta para uma nova relação entre público e cena.

Na perspectiva de pensar a relação palco-plateia proposta por arquiteturas teatrais alemãs do início do século XX, foram abordados neste trabalho alguns dos principais encenadores alemães que trabalharam num período próximo a Fuchs e suas respectivas propostas para novos espaços cênicos relacionando-as a seus posicionamentos políticos. Dentre os diretores estarão Otto Brahm (1856-1912), representante alemão do naturalismo no teatro, Max Reinhardt (1873-1943), que realizou encenações no Teatro dos Artistas de Munique, e Erwin Piscator (18931966) com sua proposta para um Teatro Total.

\section{O teatro como representação da realidade}

Jean-Jacques Roubine apresenta como uma importante interrogação do teatro moderno a questão do espaço da representação. Sobre esse espaço, aparecem duas reflexões, por um lado a arquitetura teatral, que organiza o espaço e a relação entre público e encenação; e por outro, a cenografia em si, que organiza o espaço destinado a encenação e sua relação com os atores (Roubine, 1998, p.27). O estudo do Teatro dos Artistas de Munique e das teorias propostas por Fuchs se fazem interessantes por se incluírem no contexto do teatro moderno em ambas as suas perspectivas de criação de um novo espaço cênico: tanto da arquitetura, quanto da cenografia.

Um expoente alemão do naturalismo foi a associação teatral Palco Livre ${ }^{5}$ (Freie Bühne) fundada em 1889 e cujo presidente era o crítico literário e teatral Otto Brahm. Segundo a pesquisadora Margot Berthold, o teatro era financiado pelos membros da associação e tinha como objetivo poder fazer um teatro "livre de considerações comerciais e livre da coação da censura" (2010, p.455). Inspirado pelo teatro de Meininger e pelo Théâtre Libre (Teatro Livre) de Paris, cujo diretor era André Antoine (1858-1943), o Palco Livre buscava apresentar principalmente as 
obras de dramaturgos como o norueguês Henrik Ibsen (1828-1906) e o então jovem alemão Gerhart Hauptmann (1862-1946), cuja peça Os tecelões (1892) é considerada por diferente teóricos um dos ápices do naturalismo.

No ano seguinte, em 1890, foi criada por parte dos integrantes do Palco Livre, o Palco Livre do Povo (Freie Volksbühne). Seu objetivo, segundo Anatol Rosenfeld, era de "oferecer ao povo mais modesto arte de alta categoria" (1993, p.314). Eram apresentadas peças uma vez por mês aos sócios e eram bancadas principalmente pela mensalidade dos associados e pela venda de ingressos. É interessante pensar aqui a relação entre esse público e o teatro, pois era o próprio público (os sócios) os proprietários do teatro. Rosenfeld afirma que "Se a Comédie Française é um teatro apoiado pelo Estado e propriedade dos atores, o Palco do Povo foi inicialmente perseguido pelo Estado - mas é desde então propriedade do público" (Rosenfeld, 1993, p.314).

Essa nova relação do público com o teatro é importante para pensar as novas relações entre palco e plateia que apareceram nesse momento histórico da virada do século. A plateia aparece como um elemento tomador de decisões. Dentre os associados existiam dez membros ativos que formavam um conselho, ele tomava as decisões do teatro e pensava o repertório dramático. Graças a essa associação particular, foi possível para esses artistas fugirem da censura e encenarem as peças naturalistas proibidas. A proibição ocorria principalmente devido às temáticas das peças, consideradas vulgares, que colocavam em cena personagens do povo e trabalhadores, suas problemáticas, e davam a ver problemas sociais da época. Além disso, um dos objetivos da associação era afirmar que a arte deve pertencer ao povo e não deve ser exclusividade das classes abastadas (Rosenfeld, 1993, p.314). Nesse sentido, é relevante a compreensão do encenador Erwin Piscator sobre o naturalismo, entendendo-o como o primeiro passo para perceber a importância do teatro para uma tomada de consciência do proletariado:

O teatro político, do modo pelo qual se saiu em todos os meus empreendimentos, não foi um "achado pessoal", nem tampouco resultado da reviravolta social de 1918. As suas raízes chegam ao fim do século precedente [XIX], ocasião em que irrompem na situação espiritual da sociedade burguesa forças que, conscientemente, ou apenas pela sua 
própria existência, mudam tal situação e em parte a suprimem. Essas forças vêm de dois lados: da literatura e do proletariado. Em seu ponto de intersecção surge, na arte, um novo conceito, o naturalismo, e no teatro uma nova forma, o teatro popular (Piscator, 1968, p.41).

Em 1894, Otto Brahm abandonou a direção do Palco Livre e tornou-se o diretor do Teatro Alemão (Deutsche Theater). Hauptmann continuou entregando suas peças ao diretor Brahm no novo teatro. A partir daí, o Palco Livre mudou de diretoria algumas vezes e foi, aos poucos, se desfazendo da sua forte característica naturalista, aproximando-se em algumas peças da estética simbolista.

Figura 2 - Fotografia atual das fachadas do Kammerspiele Haus e Deutsches Theater, em Berlim ${ }^{6}$

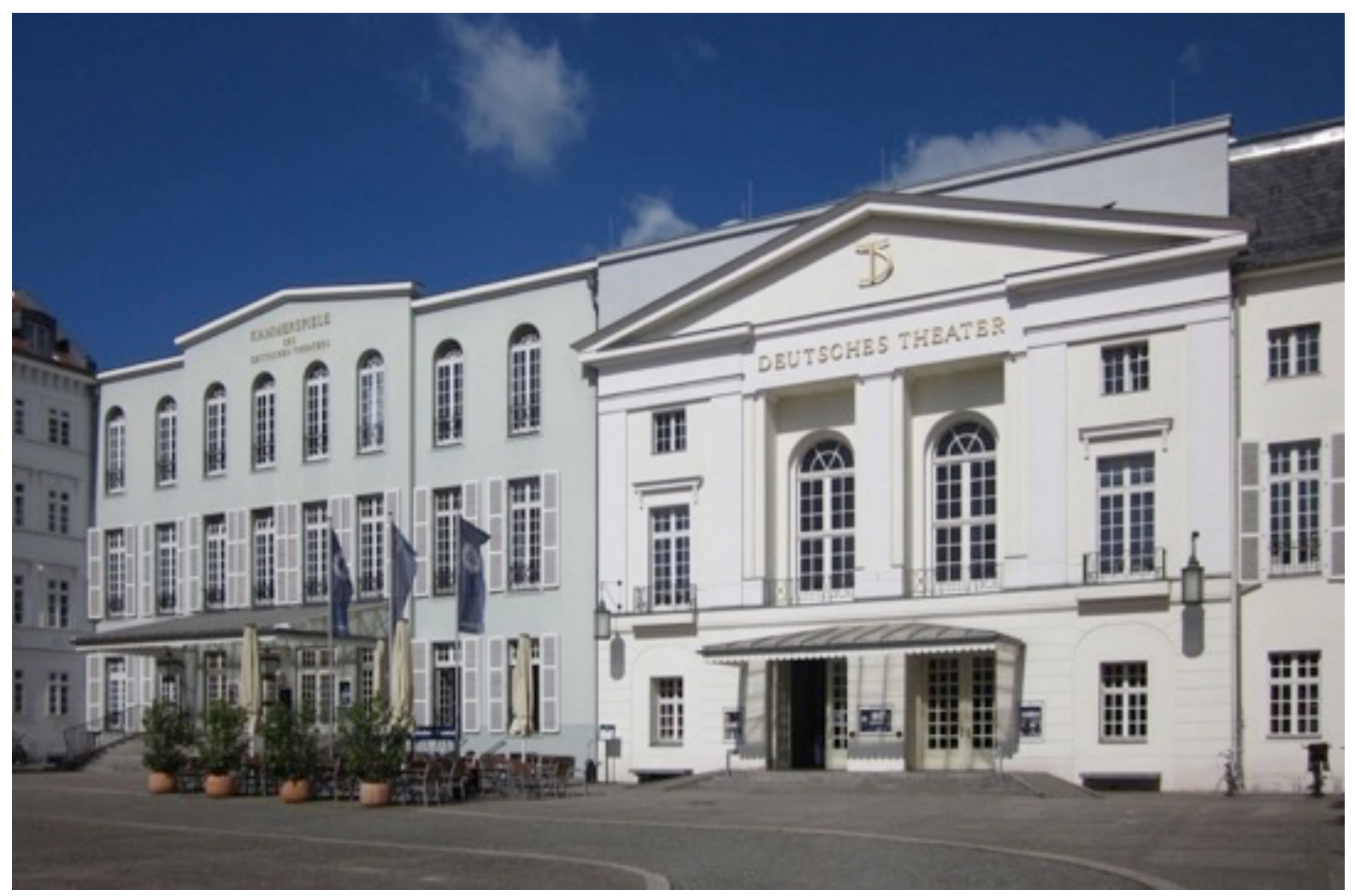

${ }^{6}$ Figura - 2 a 4 Disponíveis no sítio eletrônico do Theatre Database:

https://www.theatre-architecture.eu/en/db/?theatreld=942\&detail=attachement. Acesso em: 02 fev. 2020. 
Figura 3 - Corte lateral do prédio que abriga o Kammerspiele Haus e o Deutsches Theater

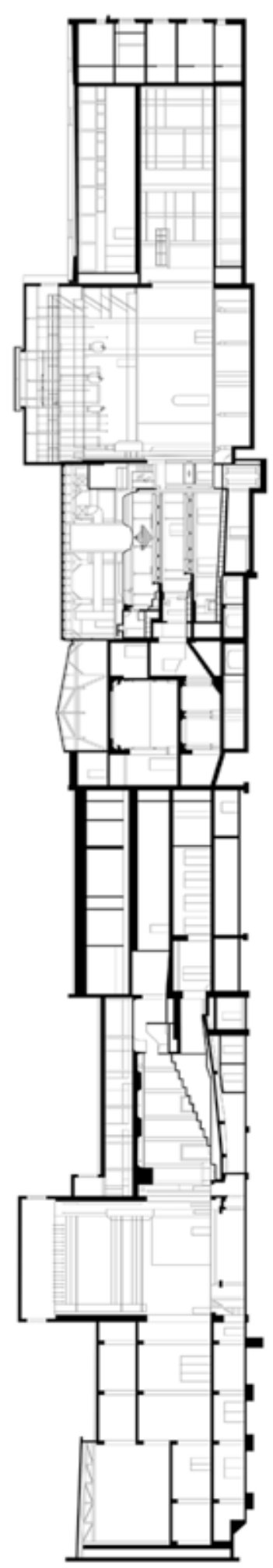


Figura 4 - Planta baixa do prédio que abriga o Kammerspiele Haus e o Deutsches Theater

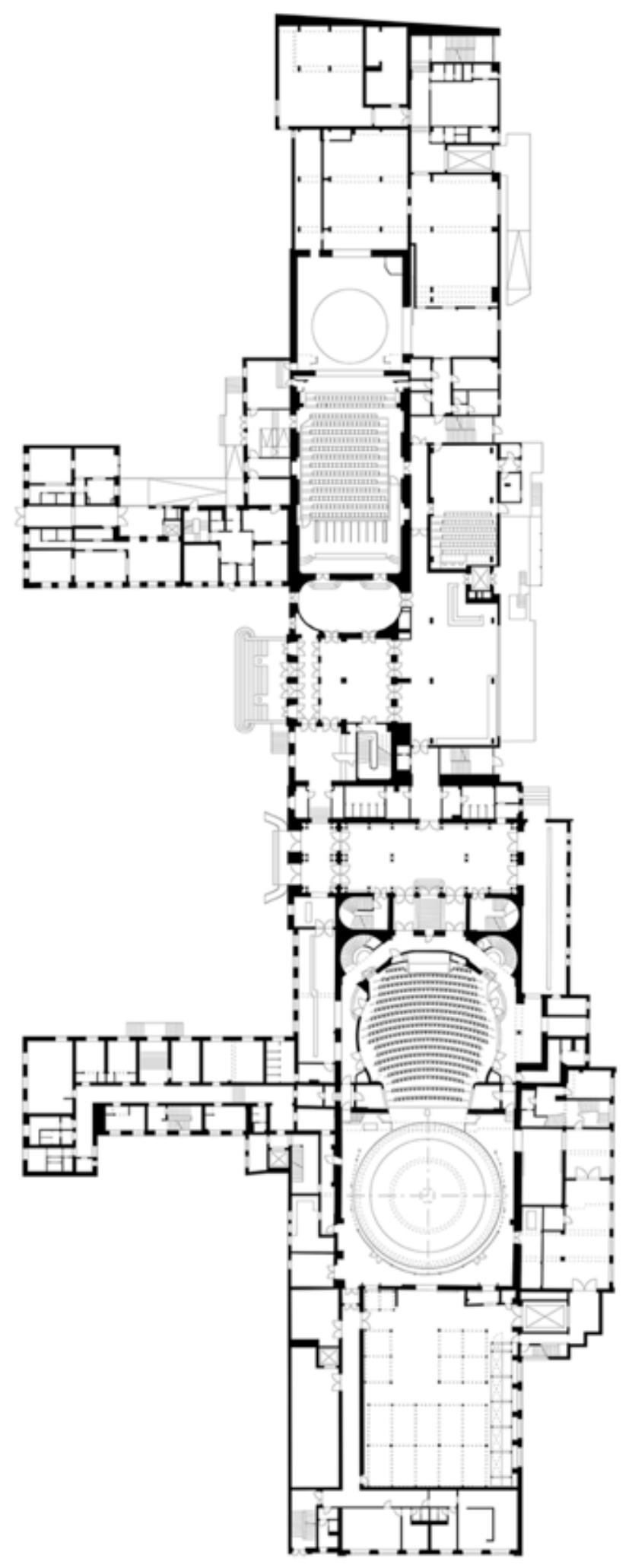




\section{teatro como uma outra realidade}

O Teatro Alemão foi construído em 1850 e, ainda hoje, mantém as principais características da sua construção original. Inicialmente criado para operetas, seu palco consiste em uma caixa cênica italiana tradicional com coxias, urdimento e sem espaço de proscênio, nem fosso para orquestra. A plateia é levemente íngreme e frontal, além dela, possui também dois andares de balcões em formato de ferradura. Ao todo possui lugar para 600 pessoas.

No Teatro Alemão, destacou-se um dos atores de Brahm, o jovem austríaco de origem judaica Max Reinhardt (1873-1943) quem posteriormente viria a ser o famoso diretor teatral admirado por Fuchs. Sobre Max Reinhardt, Fuchs afirma que ele fez um serviço relevante ao encenar as "obras primas" dramáticas sem se prender aos problemas técnicos causados por uma tentativa de verossimilhança com a realidade. Dessa maneira, Reinhardt coloca em cena textos clássicos e os torna acessíveis ao público, sempre, segundo Fuchs, com os melhores padrões de gosto. Por meio do uso consciente das artes plásticas, Reinhardt reduziu a "parafernália" cênica e fez uso de uma cenografia com poucos elementos em cena (Fuchs, 1909, p.114).

Em 1901, Reinhardt iniciou sua carreira de diretor teatral em um grupo de jovens artistas intitulado Som e Fumaça (Schall und Rauch). Esse grupo realizava apresentações de cabaré e, no ano seguinte seu nome foi mudado para Teatro Pequeno (Kleines Theater). Dois anos depois, Reinhardt dirigiu seu próprio teatro, o Teatro Novo (Neues Theater), que funcionou sob sua administração até 1933, quando ele abandonou a Alemanha devido à perseguição nazista. Ainda nesse período, o teatro abrigou as primeiras encenações do então jovem encenador Bertolt Brecht (1898-1956). Após a Segunda Guerra, o espaço do Teatro Novo se tornou o Berliner Ensemble?, administrado pelo próprio Brecht até o fim de sua vida em 1956.

\footnotetext{
${ }^{7}$ A tradução literal seria Companhia Berlinense ou Troupe Berlinense, como no Brasil a companhia de Brecht é mais conhecida pelo seu nome original em alemão do que pela tradução, a opção aqui foi de manter o original.
} 


\section{Urdimento}

Figura 5 - Fotografia da fachada do Neues Theater, em Berlim, no ano de 1908. Atualmente o prédio abriga companhia fundada por Bertold Brecht, o Berliner Ensemble ${ }^{8}$

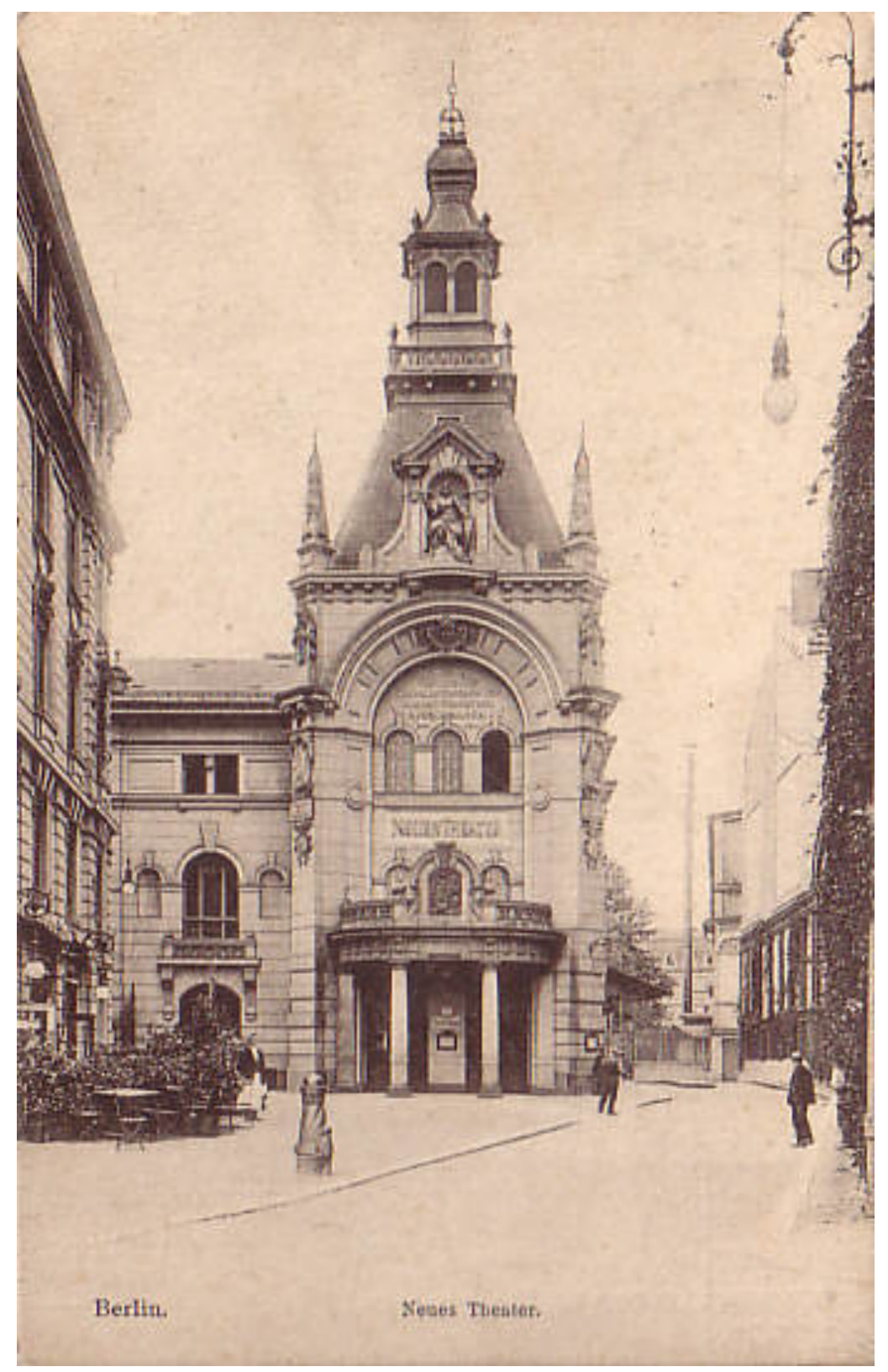

Em poucos anos, Max Reinhardt se tornou o maior empresário teatral de Berlim. Em 1905, foi diretor administrativo do Teatro Alemão (Deutsche Theater) e

${ }^{8}$ Disponível no sítio eletrônico:

https://upload.wikimedia.org/wikipedia/commons/d/da/Berlin_theater_am_schiffbauerdamm_berliner_ense mble.jpg. Acesso em: 28 jan. 2020. 
em seguida o comprou de seu fundador. No ano seguinte, Reinhardt reconstruiu uma sala de dança vizinha ao Teatro Alemão transformando-a no Teatro de Câmara (Kammerspiele Haus): um teatro íntimo, com cerca de 230 lugares em uma plateia frontal. Nesse teatro, Reinhardt encenava dramas naturalistas e minimalistas, como de Ibsen, Wedekind e Strindberg, enquanto no teatro principal encenava os clássicos. Nas figuras 3 e 4, é possível observar a planta baixa e o corte transversal dos dois teatros. Nessas imagens ficam claras as diferenças de tamanho e estrutura desses teatros.

Ambos os espaços eram equipados com palcos giratórios, que contribuíam para mudanças de cenário e efeitos na cena. Sobre a primeira encenação, das doze, realizada por Reinhardt da peça de Shakespeare Sonho de uma noite de verão, o pesquisador Cesare Molinari afirma que "O ponto central da representação era constituído pelas cenas no bosque, que foi um verdadeiro bosque, feito de árvores verdadeiras e visto, graças a uma inteligente utilização do palco giratório, em angulações sempre diferentes" (Molinari, 2010, p.375).

O reduzido Teatro de Câmara possui uma plateia completamente frontal, com grande inclinação. A plateia íngreme facilita a visão do palco e concentra uma maior quantidade de espectadores em uma menor área, aproximando cena e público. Nesse momento, surgiu por diferentes partes da Europa os chamados "teatros de câmara", que, para além do espaço físico reduzido, eram construídos para uma dramaturgia específica para esse espaço. O dramaturgo sueco August Strindberg (1842-1912), por exemplo, abriu seu Intima Teatern (Teatro Íntimo), em 1907, em Estocolmo. Apesar da ausência do proscênio no Teatro de Câmara de Reinhardt, que para Fuchs é o elemento que conecta cena e audiência, este teatro tem por objetivo gerar uma proximidade maior entre a encenação e o espectador. Como na música de câmara tocada por poucos instrumentos, para que seja possível perceber as notas emitidas por cada um deles; o Teatro de Câmara é encenado por poucos atores e, com a minuciosidade do trabalho dramatúrgico, é possivel perceber todos os seus tons e entonações. Sobre o modelo teatro de câmara, Patrice Pavis afirma: 
A voga do teatro de câmara, no início do século até nossos dias, explicase pela vontade de fazer do palco um local de encontro e de confissão recíproca entre ator e espectador, por uma grande sensibilidade para as questões psicológicas. Nesse "entre quatro paredes", o ator parece diretamente acessível ao público, que não pode recusar sua participação emocional na ação dramática e que se sente pessoalmente interpelado pelos atores. Os temas - o casal, o homem isolado, a alienação - são escolhidos para falar "diretamente" ao espectador confortavelmente instalado, quase como no divã do psicanalista, e confrontado, por ator e ficção interpostos, com sua própria interioridade (Pavis, 2008, p. 382).

Ainda em 1905, Reinhardt escreve o Manifesto Teatral de Max Reinhardt, um manifesto teórico sobre seu teatro que foi publicado no Diário de Dramaturgia (Tagebuch des Dramaturgen) editado por Arthur Kahne. Nesse manifesto, Reinhardt discorre sobre os principais objetivos do seu teatro, apresenta o ator como o elemento fundamental do teatro, reflete sobre o naturalismo e o rejeita como estilo de encenação, principalmente devido ao seu "pessimismo". Já nesse manifesto, Reinhardt apresenta sua necessidade de ter três teatros com palcos de estilos e tamanhos diferentes, para encenar tipos distintos de espetáculos.

Devem-se ter na verdade dois palcos, lado a lado, um grande para os clássicos [Deutschen Theater] e um menor [Kammerspiele Haus], um palco intimista para os poetas modernos de arte de câmara. Com dois palcos, os atores não vão conseguir usar um único estilo e vão poder se testar alternando performances nos dois palcos. Interpretando o trabalho dos poetas modernos como clássicos e certos trabalhos clássicos com a completa intimidade da arte da alma. No entanto, haverá muitas armadilhas com este arranjo. E, na verdade, deveria ter um terceiro palco. Não riam, eu digo com toda seriedade, e já o vejo na minha frente: um teatro muito grande para uma arte grande de efeitos monumentais, um festival de teatro, que é separado da vida cotidiana, uma casa de luz e consagração, no espírito dos gregos, não só para os trabalhos dos gregos mas para os maiores trabalhos de todos os tempos, na forma de um anfiteatro sem cortinas, sem panos de fundo e talvez sem nenhuma decoração. E no centro, confiando plenamente no efeito puro da personalidade e na palavra falada, estará o ator (Reinhardt apud Viana, 2010, p.112-113).

Nesse trecho alguns aspectos chamam atenção: a necessidade de um terceiro palco muito grande; a separação desse teatro da vida cotidiana, "no espírito dos gregos"; e a ausência dos elementos teatrais (sem coxias, urdimento, porão) que ocultam os meios de produção, poucos objetos em cena e a ênfase na 
palavra do ator. A separação do teatro da vida enfatiza a visão idealista da arte de Reinhardt, a proposta de fazer com que o público necessite se esquecer, ausentarse da vida para poder habitar esse outro tempo-espaço da arte. Contraditoriamente, Reinhardt aproxima essa ideia de uma inspiração pela arte grega, sem que seja levado em conta o quanto o teatro grego estava inserido na vida cultural e política da pólis.

Sobre esse terceiro teatro, voltado para "um festival de teatro", é notável a relação com o conceito de Obra de Arte Total (Gesamtkunstwerk) wagneriana e com a proposta de Fuchs para um teatro festa, capaz de envolver toda a comunidade. Ainda em 1910, Max Reinhardt alugou o Circo Schumann (Zirkus Schumann), em Berlim, para a encenação de Édipo Reide Sófocles. O espaço tinha lugar para cinco mil espectadores. Segundo Berthold, a encenação colocava em prática algumas das ideias de Edward Gordon Craig para um teatro do futuro, tais como o uso de escadas e elementos móveis no cenário, o que nos remete também ao teatro proposto por Fuchs. Nessa encenação, o teatro seria um lugar festivo, onde as multidões se reuniriam como no teatro da Antiguidade ou nas feiras da Idade Média.

Em 1919, o teatro para "efeitos monumentais" foi construído sob orientação de Reinhardt no local onde havia sido um antigo mercado da cidade que posteriormente deu espaço ao grande Circo Schumann. O espaço foi completamente re-projetado pelo arquiteto Hans Poelzig para se tornar um teatro e nomeado de Grande Casa de Espetáculos (Grosses Schauspielhaus) ${ }^{9}$. O espaço estreou com a encenação de Oréstia de Ésquilo sob direção de Max Reinhardt. O projeto arquitetônico inovador de Poelzig seguia uma estética expressionista. Segundo a pesquisadora Lotte Eisner, o interior do teatro:

[...] evocava algo como uma caverna misteriosa, decorada com estalactites; já na lareira e nos corredores, via-se brilhar o lótus de capitéis egípcios iluminados indiretamente, enquanto as arcadas estreitas do exterior, modificado por influência gótica, lembravam vagamente o estilo do Coliseu (Eisner, 1985, p.49-50).

${ }^{9}$ O teatro foi demolido em 1988 devido a comprometimentos estruturais. 
Figura 6 - Fachada do Grosses Schauspielhaus em Berlim, fundado em $1919^{10}$

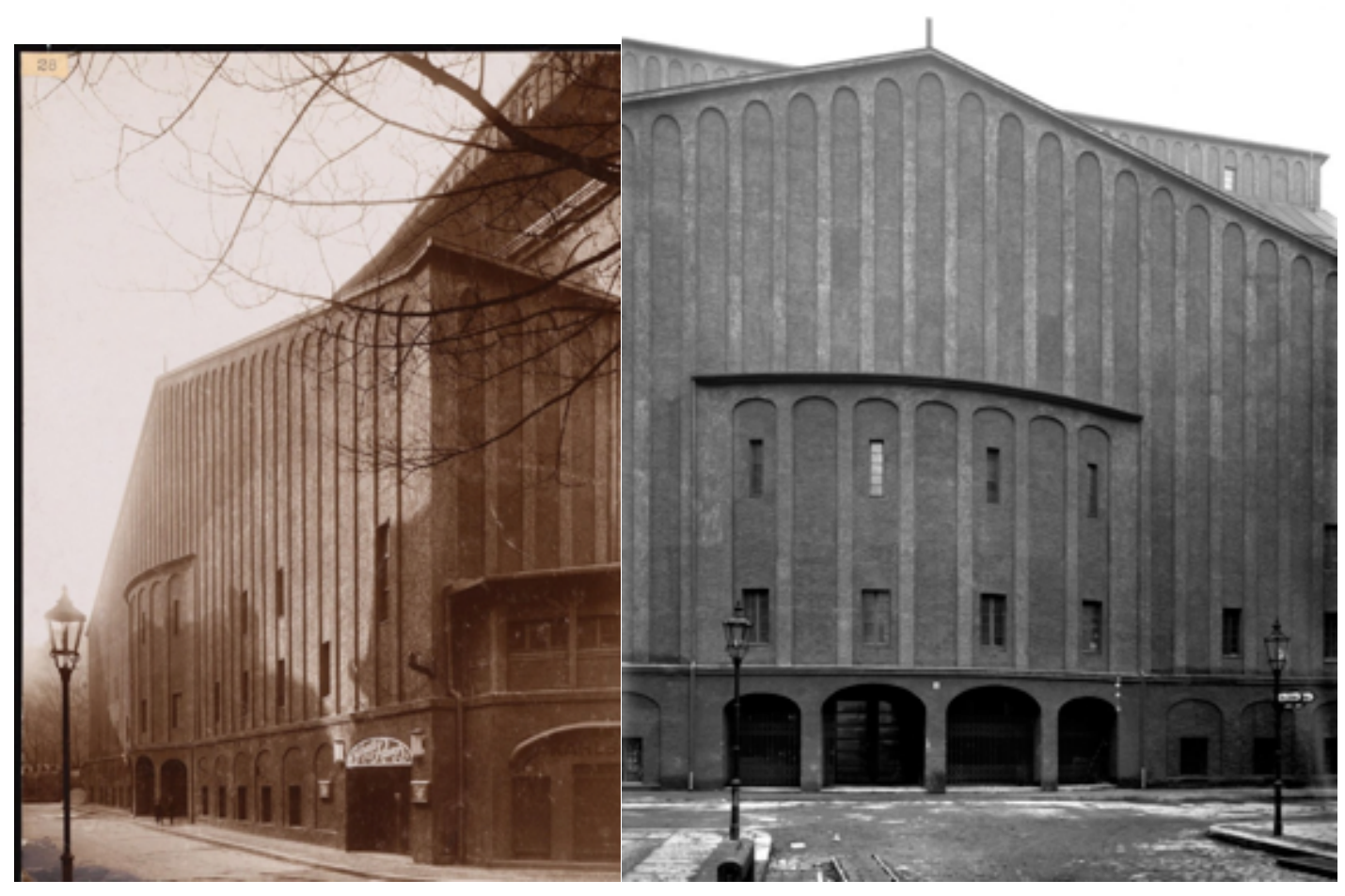

Figura 7 - Interior do Grosses Schauspielhaus vista do palco e do teto

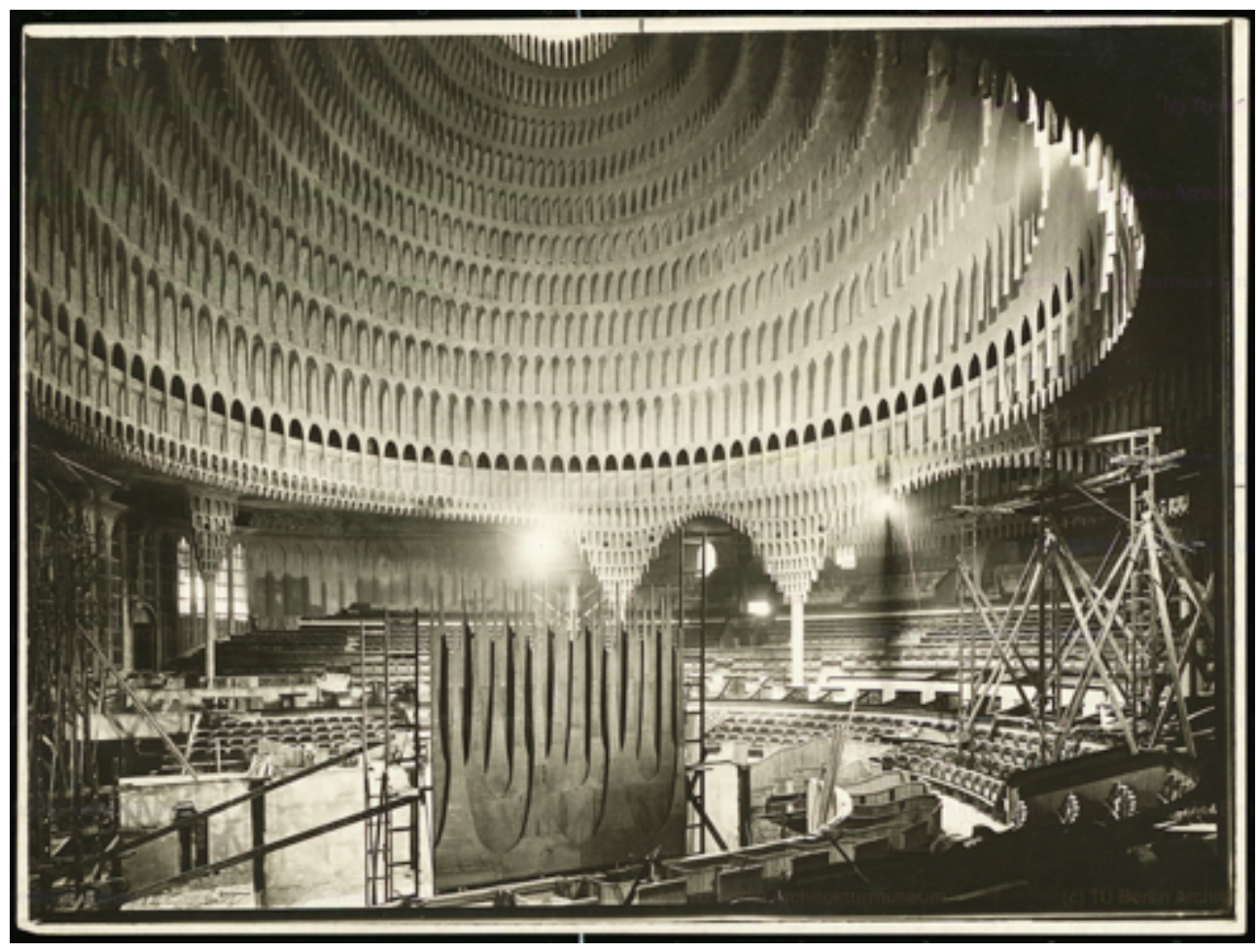

${ }^{10}$ Figuras - 6 a 11 disponíveis no sítio eletrônico: https://architekturmuseum.ub.tuberlin.de/index.php?p=51\&O=358654. Acesso em: 02 fev. 2020. 
Figura 8 - Interior do Grosses Schauspielhaus - Proscênio avantajado livre para uso da encenação

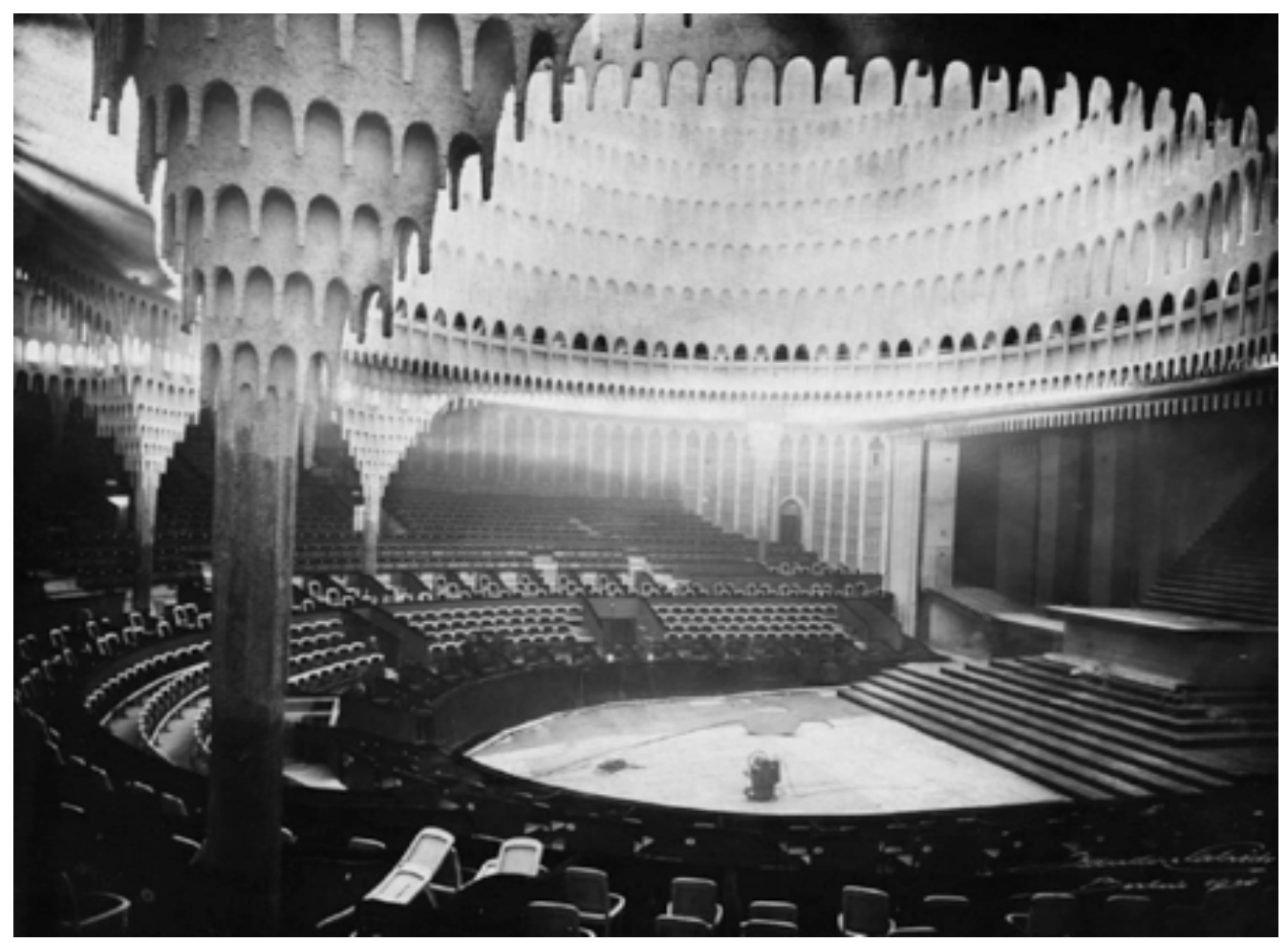

Figura 9 - Interior do Grosses Schauspielhaus - Vista da plateia, do proscênio sendo utilizado como plateia e teto com iluminação elétrica

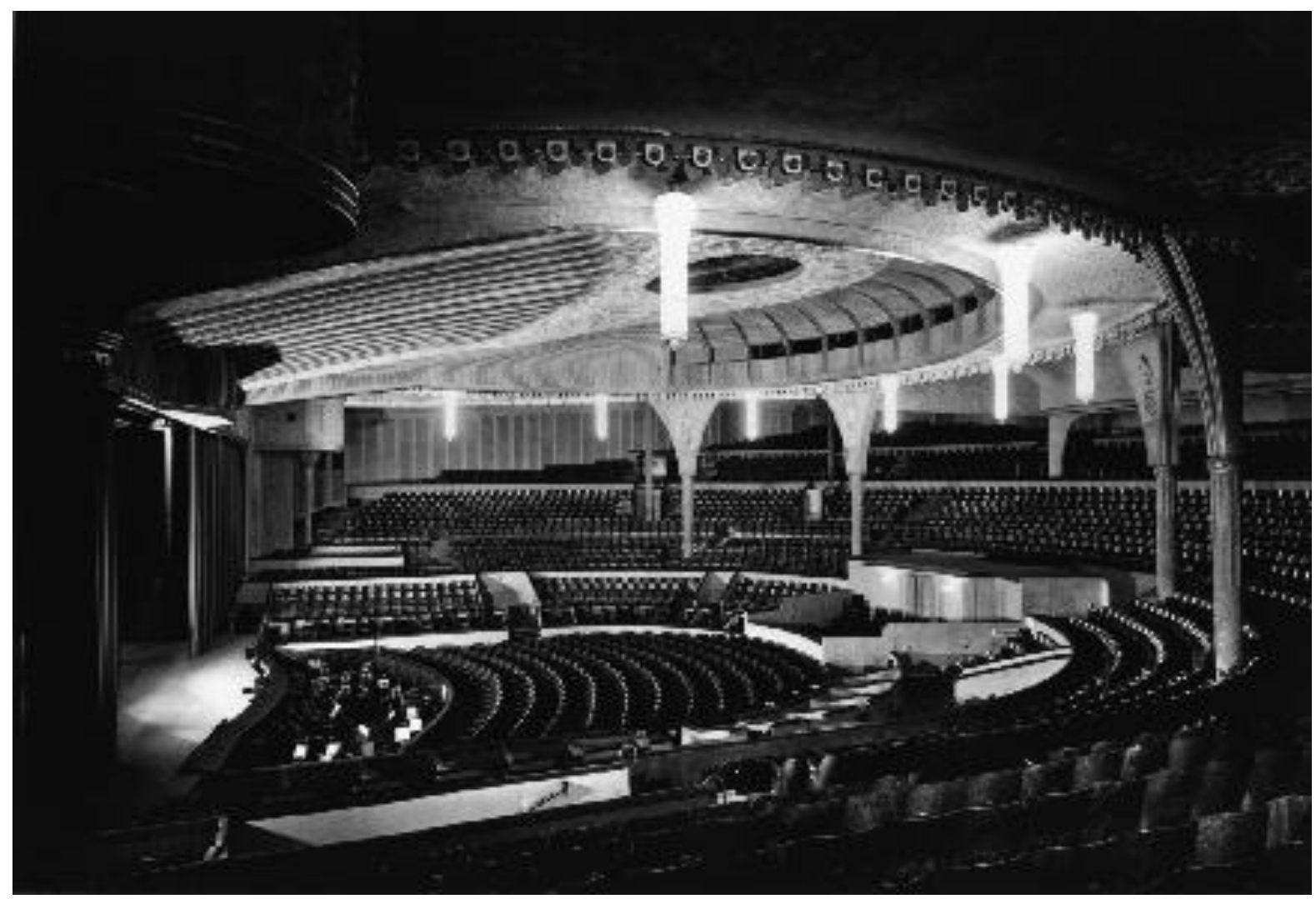




\section{Urdimento}

Figura 10 - Planta baixa do Grosses Schauspielhaus

Atentar para o tamanho do proscênio com relação ao palco

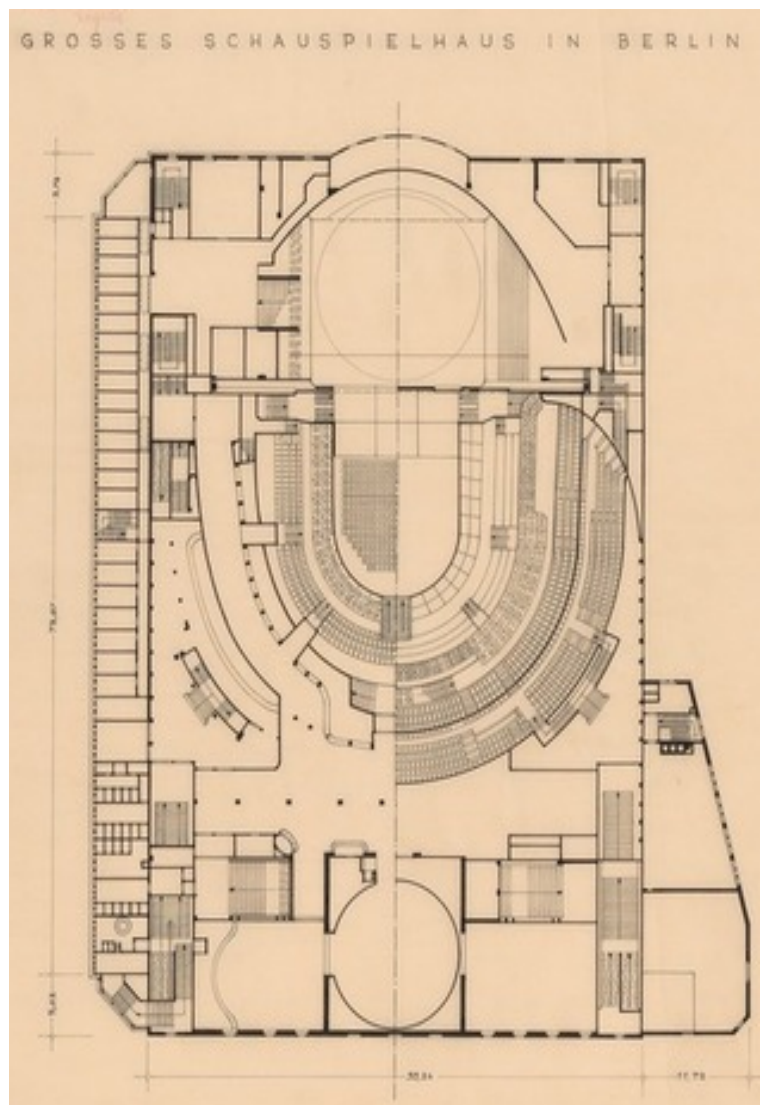

Figura 11 - Perspectiva isométrica do Grosses Schauspielhaus

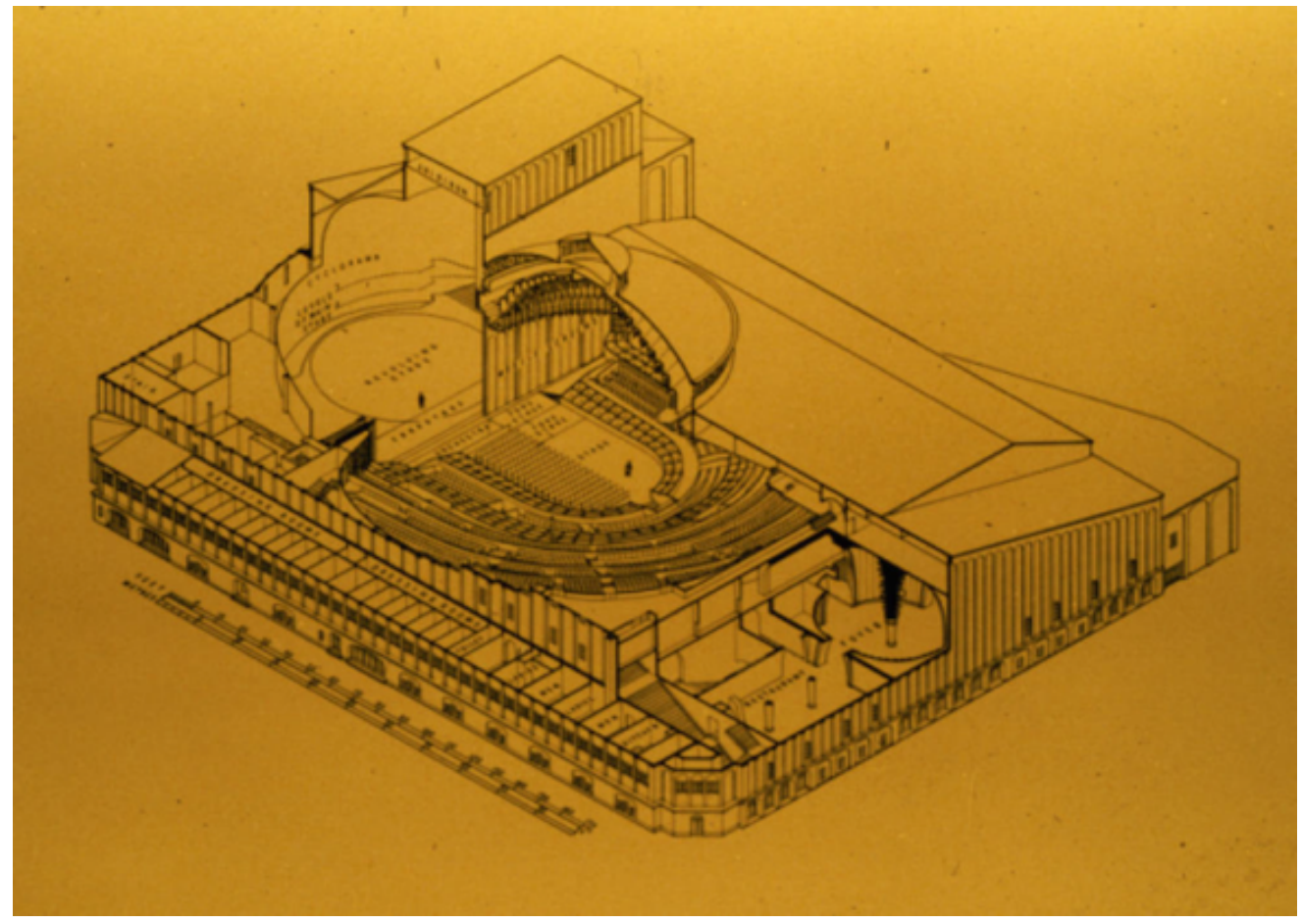


O teatro possuía iluminação elétrica, uma plateia em formato de ferradura e lugar para 3500 pessoas. O que mais chama atenção nesse teatro é a presença do que podemos compreender como dois palcos: 1) seja como um palco tradicional, porém sem coxias, com a tecnologia de um grande palco giratório e um grande ciclorama ao fundo; na frente desse palco, no mesmo nível da plateia havia um grande proscênio, quase do mesmo tamanho do palco. Essa área era usada de diferentes maneiras: ocupada por cadeiras da plateia para uma relação frontal com a cena; ou como um proscênio utilizado simultaneamente com o palco e com escadas os conectando; 2) seja como um teatro em semi arena ao estilo grego, para isso, a boca de cena do palco principal era coberta com tapadeiras deixando apenas esse palco da frente de formato arredondado a mostra. Pode-se observar ainda os camarotes no entorno do proscênio, tão próximos à cena que parecem mesmo lugares privilegiados em um teatro cujo maior intuito é fazer com que o espectador se sinta dentro da encenação. Outra estratégia utilizada por Max Reinhardt era a utilização dos corredores da plateia como área útil de atuação dos atores.

No ano seguinte da estreia, Reinhardt colocou em prática sua ideia de fazer com que o público tomasse parte da encenação de maneira ativa. Na sua montagem de Danton, atores sentados na plateia se manifestavam como revolucionários, com o intuito de agitar todo o público. Contudo, a peça não teve uma boa aprovação pela plateia conservadora. De acordo com Berthold, essa encenação foi a primeira amostra do que viria a ser a ideia de "teatro total" que habitaria as mentes de diferentes encenadores alemães.

Uma semelhança interessante a se pensar entre os teatros de Reinhardt e Fuchs é a ausência de uma proposta explicitamente política - no sentido de uma busca de transformação social e política dentro do contexto de luta de classes. Porém, essa abordagem da arte enquanto uma saída da realidade não deixa de ser também um posicionamento político. Principalmente quando se contrapõe a uma proposta de teatro comercial, no sentido de um teatro capaz de gerar lucro por meio da bilheteria e de patrocínios, como é o caso das empresas Reinhardt.

Tanto Fuchs quanto Reinhardt propõem um teatro que seja capaz de se 
manter financeiramente pela bilheteria e por uma boa administração, porém, sem que deixe de ser um teatro de arte e de "bom gosto". Para que isso fosse possível, era necessário que o teatro atraísse um número máximo de espectadores pagantes e desse a eles o que desejavam. Quando procura definir os objetivos de seu teatro, Max Reinhardt (apud Vianna, 2010, p. 111) afirma:

\begin{abstract}
O que tenho em mente é um teatro que mais uma vez vá trazer alegria às pessoas. Um teatro que conduza as pessoas das misérias da vida cotidiana para uma atmosfera cheia de beleza pura e brilhante. Estou consciente de que as pessoas não estão satisfeitas com um teatro que mostra repetidamente os sofrimentos individuais. Estou consciente que eles mais uma vez anseiam por encontrar cores brilhantes e um sentido de vida enaltecido. O que não significa que eu vá abandonar as grandes conquistas da arte naturalista de interpretação e o nível de verdade e genuinidade que nunca antes foram atingidos no palco. Eu não poderia fazer isso, mesmo que quisesse. [...] Esqueçam os problemas dos críticos da sociedade. Eu quero o mesmo nível de verdade e autenticidade das mudanças humanas genuínas encontradas numa arte psicológica profunda e sofisticada. Mais do que mostrá-la pelo seu lado de negação pessimista, eu quero a vida tão verdadeira e genuína como na sua plenitude, cheia de luz e cor.
\end{abstract}

Nesse trecho, fica explícita a crítica de Reinhardt ao teatro naturalista, principalmente ao seu caráter crítico e pessimista. Um teatro que mostra uma visão idealizada do mundo combina perfeitamente com o modo de produção capitalista que ao longo do século XX intensificou a produção de propagandas que vendem esse modo de vida. Nesse contexto, há sempre uma associação entre felicidade e bens de consumo, sejam objetos utilitários ou artísticos. Não foi por acaso, portanto, que durante a Segunda Guerra, Reinhardt imigrou para os Estados Unidos e fez sucesso com a indústria cinematográfica de Hollywood e a Broadway, permanecendo no país até sua morte.

No início do ano de 1910, foi fundada a Associação de Festas Populares de Munique (Verein Münchener Volksfestspiele), aprovada pelo governo, tal organização buscava patrocinar trabalhos de repertório clássico por toda a cidade, com o antigo ideal da criação de um teatro nacional. Vinte anos antes, as autoridades bávaras reprovaram a ideia de um teatro do povo, que aconteceria durante as comemorações da Oktoberfest e reuniria diferentes classes sociais, 
proposto pela Sociedade da Vida Moderna (Gesellschaft für modernes Leben), segundo Peter Jelavich, tachada erroneamente de socialista pelas autoridades devido ao seu viés naturalista. Contudo, o ano de 1910 pareceu ser o momento propício a se criar um teatro de múltiplas classes sociais, que se pretendia "sem um conteúdo político por detrás". Como dito anteriormente, essa pretensão apolítica sempre camufla determinados ideais políticos. Nesse sentido, Jelavich (1996, p. 213) afirma:

Em 1891, as autoridades bávaras não queriam se envolver com o "teatro folclórico" multiclasse da Oktoberfest, proposto pela Modern Life Society, que havia sido falsamente manchado com o estigma do socialismo; mas, duas décadas depois, a tendência predominante de negar as políticas partidárias por meio da coalizão [de partidos não socialistas] determinou que era finalmente o momento propício para a criação de formas teatrais que combinariam diferentes classes em uma comunidade cultural apolítica. Previsivelmente, os organizadores do Verein Münchener Volkspiele [Associação de Teatro Popular de Munique] se aproximaram de Reinhardt, que prontamente concordou em dirigir uma produção festiva apolítica para uma audiência de massa. ${ }^{11}$

Assim, Max Reinhardt foi chamado a apresentar suas encenações em 1909 no Teatro dos Artistas de Munique por três verões seguidos, nos anos posteriores a sua inauguração. Reinhardt aproveitou a oportunidade para apresentar suas produções ao grande público internacional que lotava a cidade de Munique todos os anos. A passagem de Reinhardt pelo Teatro dos Artistas e sua relação com Fuchs é pouco abordada em livros de referência12. Os trabalhos de Reinhardt que foram apresentados em Munique nos festivais de verão foram algumas das

\footnotetext{
${ }^{11}$ Back in 1891, Bavarian authorities had wanted nothing to do with the multiclass Oktoberfest "folk theater" proposed by the Modern Life Society, which had been falsely tainted with the stigma of socialism; but two decades later, the prevailing trend toward negating party politics through coalition determined that the time was finally ripe for the creation of theatrical forms that would combine numerous classes into an apolitical cultural community. Predictably, the organizers of the Verein Münchener Volkspiele approached Reinhardt, who readily agreed to direct an apolitical festive production for a mass audience. (Tradução nossa).

12 Tanto o teatro de Max Reinhardt e principalmente o de Georg Fuchs não são muito trabalhados em obras de referência disponíveis no Brasil. Diante da enorme produção teatral de Reinhardt ao longo da vida, as poucas encenações dele no Teatro dos Artistas de Munique não parecem se destacar, pois quando abordadas, ocorre sempre de maneira breve. Um pouco da relação entre Fuchs e Reinhardt é abordada no Livro Munich and Theatrical Modernism: Politics, Playwriting, and Performance, 1890-1914 (1996) de Peter Jelavich, além dele, na tese de doutorado Empathy Abstracted: Georg Fuchs and the Munich Artists' Theater (1990) de Juliet Koss. O livro brasileiro O figurino teatral e as renovações do século XX(2010) de Fausto Viana, em seu capítulo sobre Reinhardt, também oferece pistas importantes sobre suas encenações no Teatro dos Artistas de Munique. Retirando informações dessas três fontes pude chegar às encenações que o diretor apresentou nos três festivais de verão dos quais participou em Munique.
} 
montagens que já haviam sido sucesso em Berlim: O mercador de Veneza e Sonho de uma noite de verão de Shakespeare em 1909 e 1910 respectivamente, Os Bandoleiros de Schiller e Lisístrata de Aristófanes em 1909, Édipo Rei em 1910 de Sófocles. Contudo, por considerar o espaço do Teatro dos Artistas muito confinado, Reinhardt apresentou Édipo Rei no hall de exposições para três mil espectadores ao redor da cena, em formato de semi arena. Também em 1910, Reinhardt apresentou a pantomima Sumuru de Friedrich Freska, um respeitado dramaturgo modernista de Munique. A trilogia da Orestéia de Ésquilo foi apresentada em 1911, no mesmo local e formato de Édipo Rei.

Max Reinhardt não foi apenas um diretor teatral de sucesso. Ele e seu irmão, Edmund Reinhardt (1871-1929), fundaram a empresa teatral Reinhardt que produzia peças, e posteriormente filmes, em diferentes lugares do mundo e em grande quantidade. Como técnica de direção artística Reinhardt utilizava-se de cadernos de direção, nos quais escrevia todos os detalhes para uma determinada encenação. Por meio desses cadernos e de profissionais de confiança em sintonia com o diretor, Reinhardt conseguia produzir diferentes peças em cidades e países diversos ao mesmo tempo. O diretor sempre assistia presencialmente aos ensaios gerais para garantir que o trabalho realizado por seus colaboradores estariam de acordo com o que desejava. O teatro de Reinhardt, nesse sentido, estava evidentemente preocupado com o sucesso comercial, e com o atendimento dos desejos de um grande público pagante.

Reinhardt foi um encenador que não teve um estilo fechado de encenação, ele trabalhou com textos teatrais clássicos e modernos, em diferentes espaços teatrais, com públicos bem reduzidos e com grandes multidões, além de ter se utilizado de estéticas diversas de acordo com o contexto e com o período da sua trajetória. Além disso, Reinhardt introduziu no teatro elementos tecnológicos que ainda não eram utilizados, ou pelo menos não de maneira tão significativa. O palco giratório, as grandes escadarias, a luz elétrica como um elemento fundamental para a construção da cena, o uso do proscênio como componente indispensável para uma integração entre público e cena. Tais características eram propostas por Fuchs e também estavam sendo trabalhadas por outros encenadores, entre eles, 
Erwin Piscator, porém com abordagens e objetivos totalmente diferentes.

\section{O teatro como meio para uma nova realidade}

A ideia de um "teatro total" aparece de maneira bastante significativa no trabalho de Erwin Piscator (1893-1966). Inspirado pela Revolução Russa de 1917, Piscator funda em Berlim o Teatro Proletário (Proletarisches Theater) em 1919 com o intuito de propagar os ideais socialistas e atrair as massas trabalhadoras para os debates políticos. O teatro para Piscator é um instrumento da luta de classes e sua proposta era predominantemente pedagógica. Inicialmente, utilizava meios muito simples e realizava montagens nos bairros operários da cidade. Com o passar dos anos, foram introduzidas nas montagens inúmeros artifícios cênicos para a atração do público. Dentre eles, estavam músicas, danças, acrobacias, projeções, discursos, notícias de jornais, filmes, tudo para atrair a atenção do público para as questões políticas, econômicas e sociais da época.

Apesar de ter realizado encenações em edifícios das empresas Reinhardt, inclusive na Grande Casa de Espetáculos. Piscator era contrário a uma ideia de teatro desconectado da vida e foi crítico ao trabalho de Reinhardt. Para ele, o teatro precisa ser tão atual quanto uma notícia de jornal:

Diante do jornal, o teatro continuava atrasado, não era suficientemente atual, não intervinha de maneira suficientemente direta, era sempre uma forma de arte excessivamente rígida, pré-determinada e limitada do efeito. O que eu tinha em mente naquele tempo era uma ligação muito mais íntima com o jornalismo, com a atualidade do dia (Piscator, 1968, p.52).

Piscator assumiu a direção do Palco do Povo'13 (Berliner Volksbühne) em 1924 e aproveitou a oportunidade para produzir o que ele chamou de Teatro Político (Politische Theater). Em 1927, Piscator recebe críticas dos outros membros do teatro e rompe com o Palco do Povo. Inicia então a empreitada de construir um

13 Construído em 1914, o prédio do Berliner Volksbühne existe até hoje. 
palco próprio para a agitação política. Walter Gropius, (1883-1969) arquiteto e diretor da escola de design Bauhaus em Dessau, projetou um edifício teatral em consonância com as propostas de Piscator.

Figura 12 - Fotografia da fachada do Berliner Volksbühne, possivelmente datada do ano $1920^{14}$

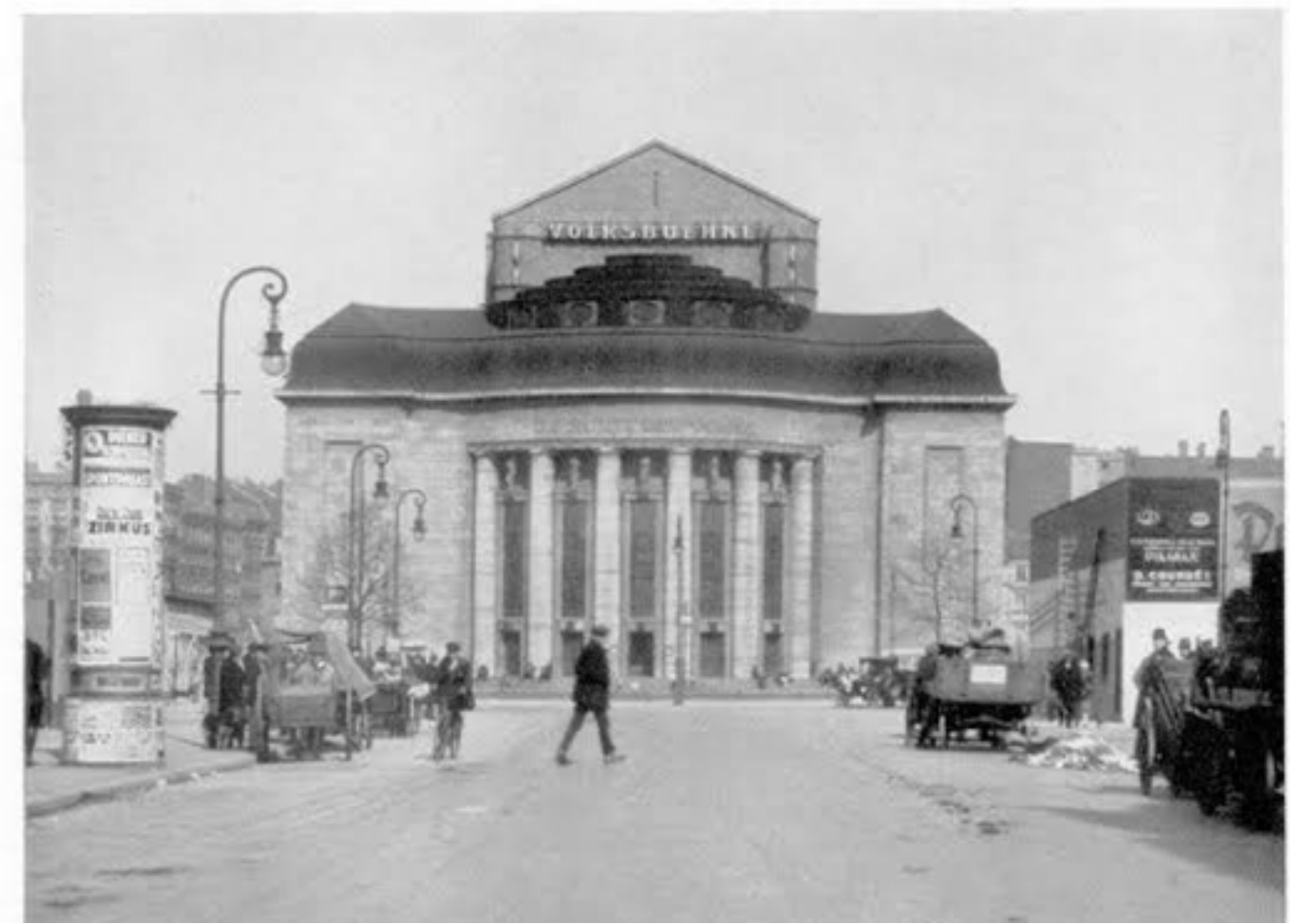

Pensando na ideia de um Teatro Total (Totaltheater), Gropius projetou uma casa de espetáculos multiuso, com palco giratório, adaptável para diferentes tipos de aparatos técnicos. A configuração entre palco e plateia do teatro poderia se modificar de acordo com a proposta do espetáculo, seria possível a configuração de um palco italiano frontal, de um palco em arena e em semi arena. Essas mudanças da configuração do palco se dava por meio de rotações do palco e de partes da plateia. Piscator desejava poder projetar cenas de filmes e imagens nas paredes de toda a sala de espetáculo, de maneira a deixar o espectador literalmente no centro da cena. Tal projeto nunca saiu do papel, e Piscator precisou alugar outro teatro na cidade para realizar suas encenações.

${ }^{14}$ Disponível no sítio eletrônico: https://www.pinterest.es/pin/381539399678047886/. Acesso em: 28 jan. 2020. 


\section{Urdimento}

A cena política, a política da cena: Reflexões sobre modernidade na arquitetura teatral alemã

Figura 13 - Projeto arquitetônico de Gropius para a fachada do Teatro Total de Piscator Desenho de perspectiva isométrica ${ }^{15}$

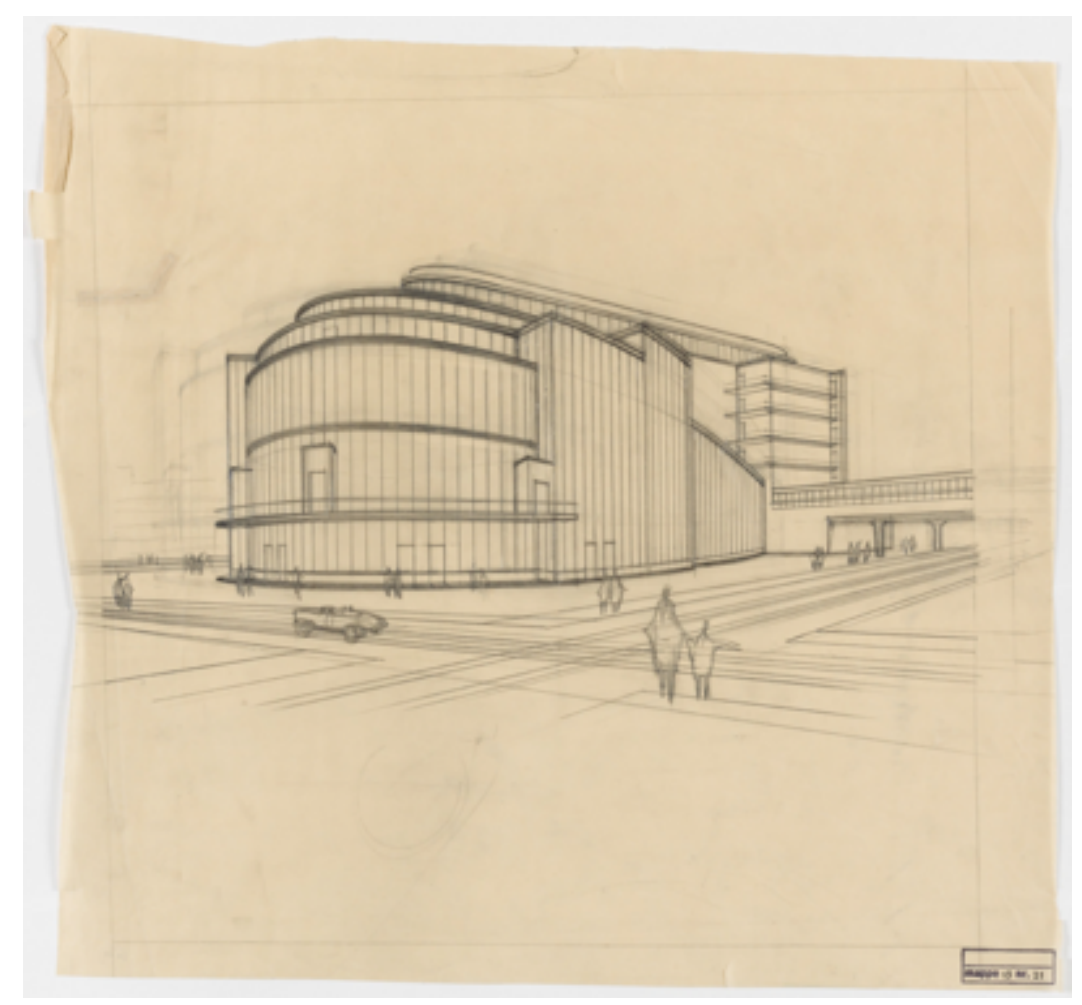

Figura 14 - Projeto arquitetônico de Gropius para o Teatro Total de Piscator - Corte lateral

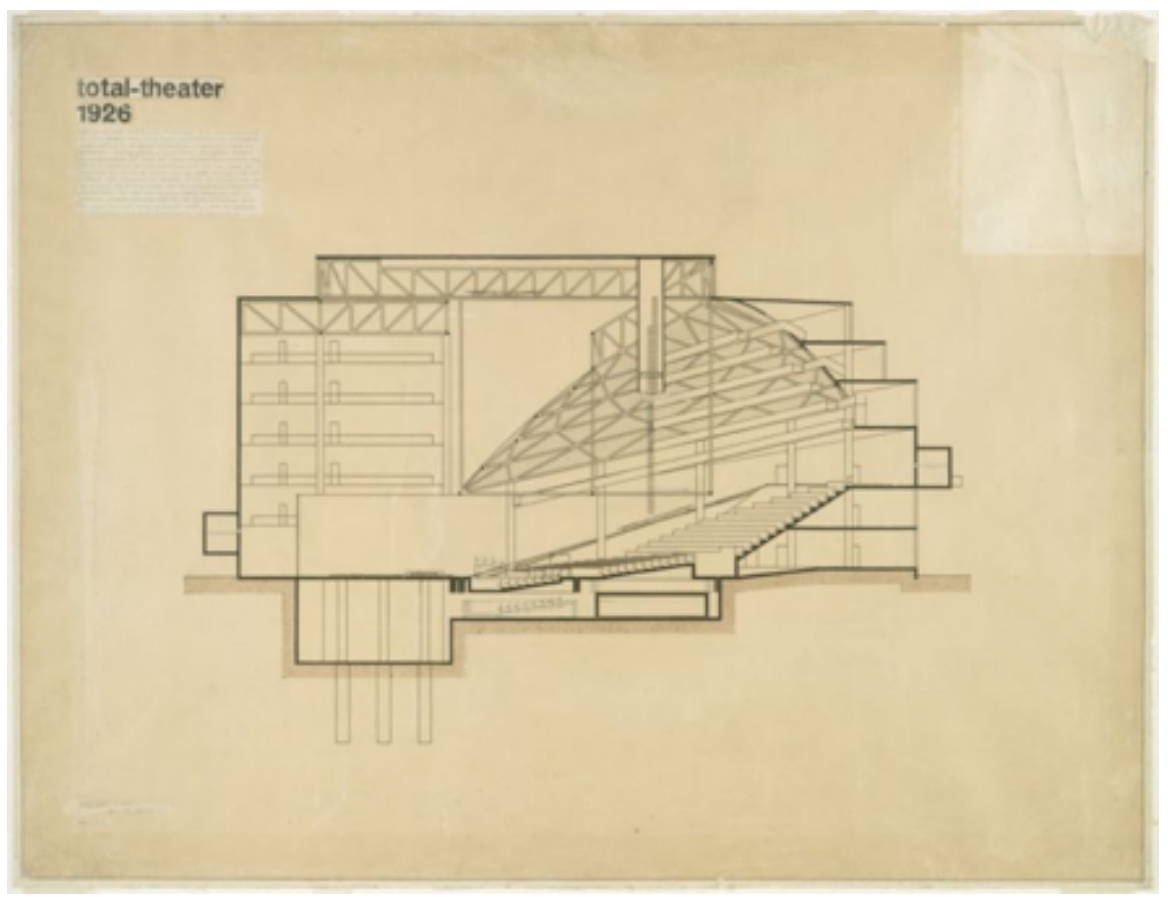

${ }^{15}$ Fig. 13 e 14 disponíveis no sítio eletrônico do Harvard Art Museum:

https://www.harvardartmuseums.org/collections?q=total+theater+. Acesso em: 02 fev. 2020. 
Figura 15 - Maquete representando a mutação da configuração de palco e plateia do Teatro Total ${ }^{16}$

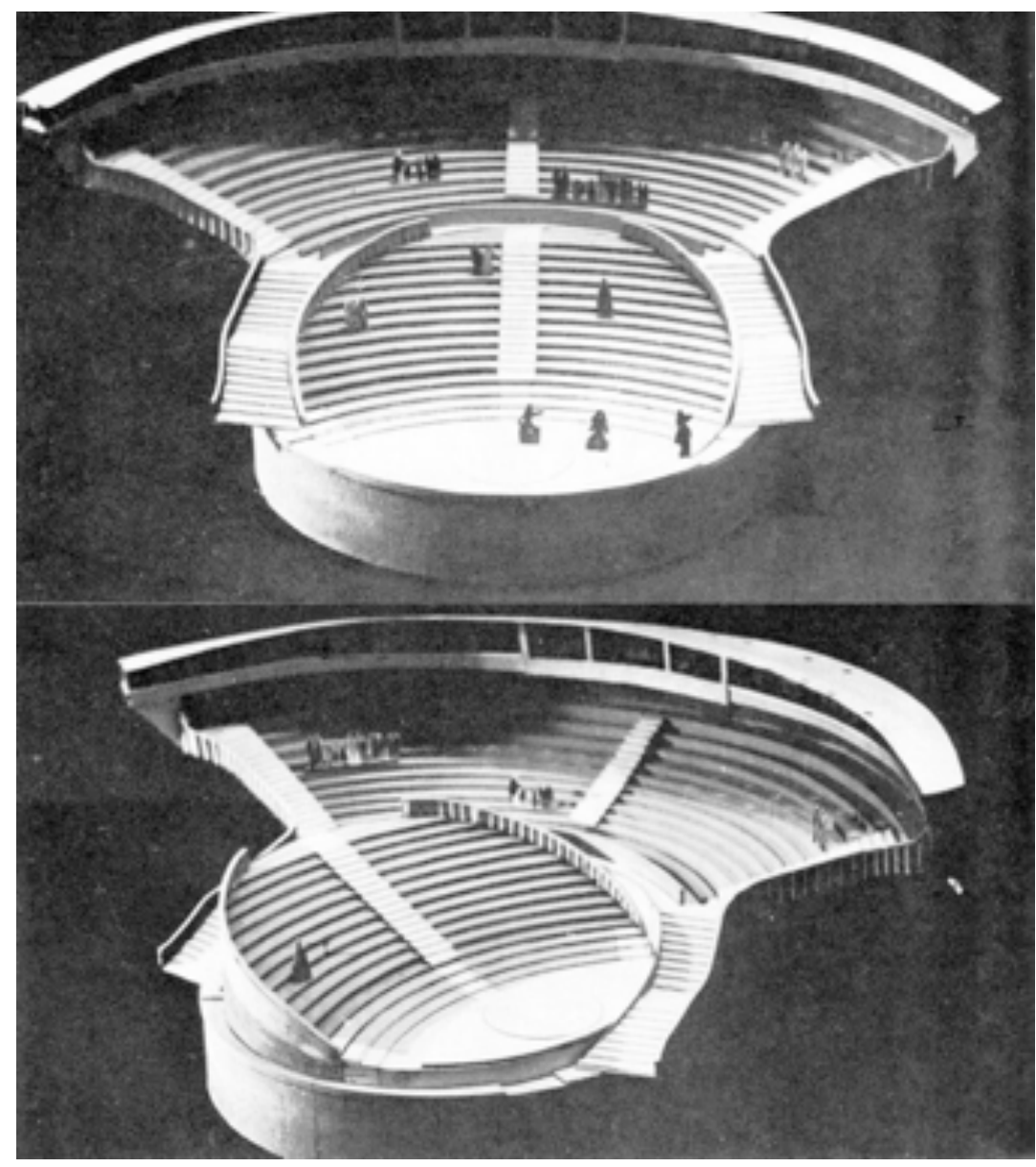

Sobre o Teatro Total de Piscator, Dort afirma que "O caminho de Piscator [foi] fazer do palco o local de uma história política total, completa” (Dort, 2010, p.373). A proposta do encenador era de intensificar o efeito da propaganda em seu grau máximo, utilizando-se de meios extra teatrais, como a projeção de notícias de jornal, cenas de filmes, imagens e textos na cena. A construção de Gropius não consistia somente em realizar um espetáculo para o maior público possível, mas principalmente em pensar as novas relações entre palco e plateia. Essas novas relações necessitavam de técnicas e aparatos modernos.

O uso dessas diferentes linguagens para encenar um mesmo evento era uma

${ }^{16}$ Figura 15 disponível no sítio eletrônico do Theatre Database: https://www.theatre-

architecture.eu/db.html?filter\%5Blabel\%5D=total\&filter\%5Bcity\%5D=\&filter\%5Bstate_id\%5D=0\&filter\%5Bon_ $\mathrm{db} \% 5 \mathrm{D}=1 \&$ filter\%5Bon_map\%5D=1\&searchMode=\&searchResult=\&theatreld=393. Acesso em: 02 fev. 2020 
maneira de ampliar a visão do espectador, de fazer com que o próprio espectador tomasse suas próprias conclusões diante das diferentes informações e estímulos mostrados no palco. Nesse sentido, o encenador não parece guiar e dar um sentido único a todos os elementos da encenação, pelo contrário, são apresentados fragmentos e quem dá sentido a eles, quem realiza a montagem é o espectador. Dessa maneira, “o palco é literalmente 'o grande teatro do mundo"” (Dort, 2010, p. 390).

No artigo Theaters of the future, o pesquisador estadunidense Arnold Aronson reflete sobre novas propostas de arquiteturas teatrais, principalmente as que envolvem recursos tecnológicos modernos, durante o século XX e como elas trabalham as relações entre cena e espectador. O autor divide as propostas arquitetônicas em duas categorias, a primeira se refere aos teatros que não mudam de fato a relação entre a cena e o espectador, nomeada de "futurismo cosmético"; e a segunda se refere aos teatros em que o próprio projeto arquitetônico traz mudanças efetivas na relação do público com a encenação, esses casos foram nomeados de "teatros do futuro".

Nesse texto, Aronson traz algumas reflexões pertinentes para essa discussão: o compositor alemão Richard Wagner (1813-1883) teria sido um dos primeiros encenadores a criar uma arquitetura pensando em uma nova relação entre a cena e o espectador; todos os "teatros do futuro" pensados no artigo de Aronson não foram de fato construídos, como o Teatro Total projetado por Gropius e o teatro de palco anular projetado pelo designer austríaco Oskar Strnad. Por fim, Aronson reflete: e se esses teatros do futuro tivessem sido construídos, como seriam as dramaturgias pensadas para eles? Sobre o teatro de Piscator, Aronson afirma:

Erwin Piscator, da mesma forma, queria um teatro flexível para suas produções - um que fosse capaz de envolver os espectadores e, ao mesmo tempo, que permitisse o máximo uso da tecnologia e de outras mídias. Ele encomendou a Walter Gropius, fundador da Bauhaus, para projetar um teatro desses em 1927. O "Teatro Total" foi o resultado, mas, como a proposta de Strnad, nunca foi construído. No entanto, ao contrário do plano de Strnad, Gropius resolveu o problema de visibilidade, colocando o palco anular fixo acima do nível da plateia ligeiramente inclinada. O palco anular circunscreveu uma área oval do auditório com 
assentos fixos. Doze pilares estreitos, entre os quais as telas de projeção podiam ser esticadas, separavam o palco e o auditório. Um palco profundo, do tipo frontal, ocupava a posição convencional, mas dos pilares dois o dividiam em um palco tripartido "que abraça as filas avançadas da plateia como um par de pinças". A grande flexibilidade desse teatro, no entanto, deriva de duas plataformas circulares que ocupam quase toda a metade da frente do auditório, o que permite que o teatro seja usado de maneira frontal, semi arena ou de arena. A plataforma maior - dentro da qual existe um circulo menor descentralizado - pode ser baixada para o porão, ter seus assentos removidos e ressurgir como um palco semi arena ou arena, dependendo da sua posição.

O objetivo de Gropius era destruir a separação psicológica implícita entre o intérprete e o espectador, eliminar a bi-dimensionalidade do cenário e criar uma plasticidade dinâmica. Ao fazer isso, ele esperava incentivar o público a "sair da inércia". O Teatro Total deveria ser uma "mobilização de todos os meios espaciais para despertar o espectador de sua apatia intelectual, surpreendê-lo e arrebatá-lo, incentivando-o a participar da peça"17 (Aronson, 1981, p.494-495).

Com a proposta de utilizar esse novo tipo de palco, a tentativa de Piscator foi de reconstituir a unidade palco-plateia por meio da luta revolucionária. Ou seja, a massa que assiste a peça de fato viveu o acontecimento apresentado, era a própria história das pessoas presentes ali. "Com Piscator, é o encenador quem transforma o privado em História, dotando o palco do poder de dizer tudo" (Dort, 2010, p.373). Assim, deixa de existir uma encenação diante do público, mas sim, uma grande sala de reunião, uma grande manifestação, uma maneira do público reviver sua própria história. O teatro se torna assim, segundo Dort, "um local privilegiado onde

\footnotetext{
${ }^{17}$ Erwin Piscator, likewise, wanted a flexible theatre for his productions - one which was capable of surrounding the spectators and at the same time would allow the fullest use of technology and other media. He commissioned Walter Gropius, founder of the Bauhaus, to design such a theatre in 1927. The "Totaltheater" was the result, but like Strnad's proposal, it was never built. Unlike Strnad's plan, however, Gropius solved the problem of sight lines by placing the stationary annular stage above the level of the slightly raked auditorium.13 The annular stage circumscribed an oval auditorium area containing fixed seating. Twelve narrow pillars, between which projection screens could be stretched, separated the stage and auditorium. A deep proscenium-type stage occupied the conventional position but two of the pillars sectioned it into a tripartite stage "which embraces the forward rows of the audience like a pair of tongs." The great flexibility of this theatre, however, derived from two circular platforms occupying nearly the entire front half of the auditorium which allowed the theatre to be used in a proscenium, thrust, or arena fashion. The larger platform- within and to one edge of the larger one - could be lowered to the basement, have its seats removed, and resurface as a thrust or arena stage, depend-ing on its position.

Gropius's goal was to destroy the implicit psychological separation of the performer and spectator, to eliminate the flatness of the stage picture and create a dynamic plasticity. In so doing he hoped to encourage the audience to "shake off its inertia." The Totaltheater was to be a "mobilization of all spatial means to rouse the spectator from his intellectual apathy, to assault and overwhelm him, coerce him into participation in the play." (Tradução nossa)
} 
se revela a "legitimidade das revoluções" (Dort, 2010, p.390). Faz-se necessário retomar aqui a ideia - comum no início do século XX e que de alguma maneira perpassa todos esses encenadores que foram abordados, desde Wagner - de recriar um teatro político de massa, inspirado na experiência grega, apesar de cada um deles ter sua própria perspectiva sobre o assunto.

\section{Considerações finais}

Ao contrário do desejado por diferentes artistas da virada do século, no período pós grandes guerras o público de teatro se tornou cada vez mais diverso. Dessa maneira, surgiram cada vez mais uma grande quantidade de teatros menores e diferentes entre si. Assim, as tentativas de criação de um teatro que unisse toda a cidade ficaram apenas como uma utopia.

Uma das mudanças mais consideráveis incide sobre a composição do público. Contrariamente ao que se passou no início do século XIX, O público não se tornou no século XX - apesar de todas as tentativas feitas nesse sentido - um público de massa. Ao contrário: embora tenha aumentado um pouco desde a guerra, não parou de se diferenciar, de se dividir, de se fragmentar. [...] Assim, os arquitetos foram obrigados a abandonar, com certo atraso, seus projetos de construção de teatros destinados a vários milhares de espectadores. [...] O sonho de um teatro que reunisse toda a Cidade parece definitivamente ter passado de moda. [...] a plateia e o palco não comungam mais da certeza de possuir uma verdade válida para todos e para o mundo inteiro. O edifício teatral só está no centro relativamente; não é mais detentor de uma verdade geral e universal. Isto quer dizer que o grande teatro de participação política, [...] não é mais, com suas exigências de unidade e de totalidade, senão um mito (Dort, 2010, p. 386-388).

A partir da experiência desses encenadores pode-se perceber como o teatro foi transformado de acordo com as intenções de transformação social e política dos seus idealizadores. Como afirma Dort, com o passar do século XX, e principalmente após a experiência do nazismo, a ideia de se reunir fisicamente em um grande teatro toda uma sociedade perdeu força.

[...] o uso que foi feito, nos anos trinta, das festas políticas, lançou sobre elas um certo descrédito. O fascismo e o nazismo se serviram das 
mesmas para celebrar uma unidade nacional que estava longe de ser revolucionária. Mas ainda, a teatralização da vida política que então ocorreu provocou, como consequência, uma desconfiança quanto ao teatro de massa e seu temível poder de mistificação (Dort, 2010, p. 386).

Enquanto o "poder de mistificação" do teatro de massas gerou "desconfiança", foi necessário ao longo do século criar novas maneiras mistificadas de controle das massas. Apesar de não ter sido trabalhado aqui, essa discussão evidencia o porquê do teatro de Brecht ser considerado tão revolucionário, pois ele esteve sempre trabalhando com a tomada de consciência dos modos de produção do próprio teatro e, consequentemente, da sociedade. Diante dessa aversão aos teatros de massa e, ao mesmo tempo, com o surgimento do teatro brechtiano, foram criadas outras maneiras de unificação ideológica das massas. A arte muitas vezes aparece como uma ferramenta para isso, sobretudo na sociedade capitalista. Ao longo dos séculos XX e XXI, outros meios de comunicação como o rádio, a televisão, o cinema e, mais recentemente, a internet e as redes sociais, mostraram-se mais eficientes do que o teatro para realizar essa mistificação política.

\section{Referências}

ARONSON, Arnold. The theatres of the future. In: Theatre Journal, v.33, n.4. The John Hopkins University Press, 1981.

BERTHOLD, Margot. História mundial do teatro. Tradução de Maria Paula V. Zurawski, J. Guinsburg, Sérgio Coelho e Clóvis Garcia. São Paulo: Perspectiva, 2010.

DORT, Bernard. O teatro e sua realidade. Tradução de Fernando Peixoto. 2a ed. São Paulo: Perspectiva, 2010.

EISNER, Lotte H. A tela demoníaca: as influências de Max Reinhardt e do expressionismo. Tradução de Lúcia Nagib. Rio de Janeiro: Paz e Terra: Instituto Goethe, 1985.

FUCHS, Georg. Die Revolution des Theaters: ergebnisse aus dem Münchener künstler-theater. München und Leipzig: Georg Müller, 1909.

FUCHS, Georg. The revolution of the theatre: conclusions concerning the Munich 
Artists Theatre. Condensed and adapted from de german by Constance Connor Kuhn. N.Y/ London: Kennikat Press, 1959.

JELAVICH, Peter. Munich and Theatrical Modernism: Politics, Playwriting, and Performance, 1890-1914. Cambridge, Massachusetts, and London, England: Harvard University Press, 1996.

KOSS, Juliet. Empathy Abstracted: Georg Fuchs and the Munich Artists' Theater. Massachusetts, US, 2000, p. 362.

MOLINARI, Cesare. História do teatro. Tradução de Sandra Escobar. Lisboa: Edições 70 LDA, 2010.

PAVIS, Patrice. Dicionário de teatro. Tradução sob direção de J. Guinsburg e Maria Lúcia Pereira. 3.ed. São Paulo: Perspectiva, 2008.

PISCATOR, Erwin. Teatro político. Tradução de Aldo Della Nina. Rio de Janeiro: Editora Civilização Brasileira, 1968.

ROSENFELD, Anatol. História da literatura e do teatro alemães. São Paulo: Perspectiva, Editora da Universidade de São Paulo; Campinas: Editora da Universidade Estadual de Campinas, 1993.

ROUBINE, Jean-Jacques. Linguagem da encenação teatral. Tradução de Yan Michalski. 2ed. Rio de Janeiro: Zahar, 1998.

VIANA, Fausto. O figurino teatral e as renovações do século XX. São Paulo: Estação das Letras e Cores, 2010. 